\title{
Substance Abuse Profiles of Patients Admitted to the Alcohol and Drug Addiction Research, Treatment, and Education Center in Turkey
}

\author{
Alkol ve Madde Bağımlılığı Araştırma, Tedavi ve Eğitim Merkezi Birimi'nde \\ Yatan Hastaların Madde Kullanım Profili-Türkiye
}

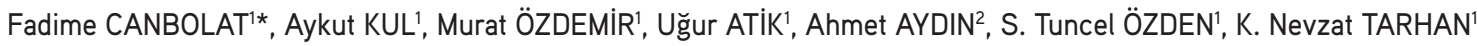 \\ 1Üsküdar University, Advanced Toxicology Analysis Laboratory, İstanbul, Turkey \\ ${ }^{2}$ Yeditepe University, Faculty of Pharmacy, Department of Toxicology, İstanbul, Turkey
}

\begin{abstract}
Objectives: To determine the substance abuse profiles of patients treated a Drug Addiction Research, Treatment, and Education Center (AMATEM) in association with the percentage of substance use distribution and multiple substance use in their urine samples. For this, we retrospectively evaluated the urine sample analysis reports of 600 male and female patients aged 13 to 65 years who were treated at the AMATEM unit of İstanbul Neuropsychiatry Hospital between January $1^{\text {st }}, 2015$, and December $12^{\text {th }}, 2015$.

Materials and Methods: The urine samples were sent to Üsküdar University Advanced Toxicology Analysis Laboratory and were analyzed using a UPLC tandem mass spectrometer (UPLC-MS/MS). To determine the substance use profiles of the patients applying to AMATEM, statistical assessment was performed on the analysis reports of the patients.

Results: When the analysis reports of the 600 urine samples were examined, 293 patients were identified to have used addictive substances. The substances most frequently detected in the urine samples were respectively: cannabis, alcohol, morphine, cocaine, synthetic cannabinoids, 3,4-Methylenedioxymethamphetamine, and amphetamine.

Conclusion: The findings in our study resemble the rates of cannabis use by the young population throughout the world. Our results show differences to the literature regarding the consumption of synthetic cannabinoids because the variety of synthetic cannabinoids change rapidly around the world each year.
\end{abstract}

Key words: Mass spectrometer, substance abuse, urine, statistical assessment

ÖZ

Amaç: Çalıșmamızın amacı, AMATEM biriminde tedavi gören hastaların madde kullanım profilini onların idrar örneklerindeki madde kullanım yüzde dağııımlarına ve çoklu madde kullanımlarına göre belirlemektir. Bunun için, İstanbul Nöropsikiyatri Hastanesi AMATEM biriminde 1 Ocak 2015 - 12 Aralık 2015 tarihleri arasında tedavi gören 13 ve 65 yaş aralığında erkek ve kadın 600 hastanın idrar örneklerinin analiz raporları retrospektif olarak değerlendirildi.

Gereç ve Yöntemler: İdrar örnekleri Üsküdar Üniversitesi İleri Toksikoloji Analiz Laboratuvarı'na gönderildi ve orada UPLC kütle spektrometresi ile (UPLC-MS/MS) analiz edildi. AMATEM birimine başvuruda bulunan hastaların madde kullanım profillerini tanımlamak için hastaların analiz raporları üzerinden istatistiksel değerlendirme yapılmıștır.

Bulgular: Altı yüz idrar örneğinin analiz raporu incelendiğinde, hastaların 293'ünde bağımlılık yapıcı madde kullanımı belirlenmiştir. İdrar örneklerinde çoğunlukla tespit edilen maddeler sırasıyla; esrar, alkol, morfin, kokain, sentetik kannabinoitler, 3,4-metilendioksimetamfetamin ve amfetamindir.

Sonuç: Çalışmamızın sonuçları bütün dünyada genç nüfus tarafından esrar kullanım oranı ile benzerlik göstermektedir. Ayrıca, sentetik kannabinoitlerin çeșitliliği her yıl dünyada hızla değiștiği için çalıșmamızın sonuçları ve literatüre sonuçları sentetik kannabinoit tüketimi konusunda farklılık göstermektedir.

Anahtar kelimeler: Kütle spektrometresi, madde kullanımı, idrar, istatistik değerlendirme

*Correspondence: E-mail: fadime.canbolat@uskudar.edu.tr, Phone: +90 5325749263 ORCID-ID: orcid.org/0000-0002-7720-4904

Received: 21.07.2016, Accepted: 02.03.2017

๑Turk J Pharm Sci, Published by Galenos Publishing House. 


\section{INTRODUCTION}

Substance abuse and dependence is a chronic disease that lasts a lifetime. Substance dependence is a global concept. The addictive substances are mainly alcohol, cannabis, opiates, amphetamine groups, cocaine, and synthetic cannabinoids. In the United Nations Office on Drugs and Crime (UNODC) 2015 world drug report, it was announced that 246 million people around the world within the age group of 15-64 had taken a drug at least once in the last year. This number indicates that approximately one in every twenty people aged between 15-64 years has taken a drug in the last year. ${ }^{2}$ Cannabis is the most commonly used drug across the world. Amphetamine-type Stimulants are the second most common drugs. Amongst the synthetic drugs, ecstasy has become the most widely used synthetic drug in the industrialized world. Opiate and cocaine groups follow in the ranking. ${ }^{3}$ Along with these, new synthetic addictive substances began to emerge near the end of 2006. Use of synthetic cannabinoids has grown exponentially worldwide. ${ }^{4}$

Substance abuse and dependence is a health issue with biologic, mental, and social aspects that can affect anyone, but primarily young people, in Turkey, and globally. ${ }^{5}$ In Turkey, the most commonly produced and consumed illegal drug is cannabis. ${ }^{6}$ The identification of the psychoactive substance relies greatly on information provided by the patient, examination of blood, urine, and saliva samples or other traces (drug samples possessed by the patient, clinical symptoms and findings, information obtained from third parties). When the detection periods of substances and metabolites are taken into consideration, urinalysis is widely preferred due to its longer periods of detection for substances and metabolites in the urine. ${ }^{7}$ However, data reflecting the dimensions of substance dependence in Turkey heavily rely on arrests by the Narcotics Police and some survey data. Accordingly, in order to obtain more reliable results, we differently evaluated the prevalence of addictive substances by using direct analysis and reports of patient's urine.

In this study, we determined substance abuse profiles of patients treated at the AMATEM unit in association with the percentage of substance use distribution and multiple substance use in urine samples. For this, we retrospectively evaluated the urine sample analysis reports of 600 male and female patients aged 13 to 65 years who were treated at the AMATEM unit of İstanbul Neuropsychiatry Hospital between January $1^{\text {st }}, 2015$, and December $12^{\text {th }}, 2015$. The urine samples were sent to Üsküdar University Advanced Toxicology Analysis Laboratory and analyzed. Statistical assessment was performed on the analysis reports to determine the substance use profiles of the patients.

\section{MATERIALS AND METHODS}

\section{Ethics statement and sample selection}

We applied to the Ethics Committee of Üsküdar University and the study was approved. The urine samples of the 600 patients, which were obtained during the initial admission periods at the AMATEM Unit, were analyzed between January 1st, 2015, and December $12^{\text {th }}, 2015$, in the Advanced Toxicology Analysis Laboratory of Üsküdar University.

\section{Urine samples preparation}

For the detection of a total 25 addictive molecules such as ethyl alcohol, cocaine, amphetamine, 3,4-Methylenedioxymethamphetamine (MDMA), cannabis, morphine, 19 synthetic cannabinoid molecules in the urine samples were analyzed using the validated method in a Waters UPLC-MS/ MS. The detection of ethyl alcohol in urine was performed by identifying its metabolite ethyl glucuronide; the detection of cannabis in urine was achieved through the identification of its metabolite 11-nor-THC-9-carboxylic acid ( $\mathrm{THC}-\mathrm{COOH})$, and the detection of cocaine in urine was achieved by determining its metabolite benzoylecgonine. The sample preparation methods are given in Table 1.

\section{UPLC-MS/MS condition}

The urine samples were analyzed using a Waters UPLC/ ICLASS Xevo TQD tandem mass spectrometer (UPLC-MS/ MS). The (multiple reaction monitoring) MRM parameters of the molecules and the internal standards are shown in Table 2.

\section{Table 1. Sample preparation}

The detection of ethyl alcohol

$1000 \mu \mathrm{L}$ formic acid (1\%)

$100 \mu \mathrm{L}$ urine sample

$+$

$100 \mu \mathrm{L}$ ethyl beta D-Glucuronide-D5

(internal standard)
Detection of amphetamine, MDMA, and benzoylecgonine

$1000 \mu \mathrm{L}$ urine sample

Benzoylecgonine-D3

(internal standard)

$500 \mu \mathrm{L}$ cold acetonitrile
Detection of THC-COOH, morphine, and synthetic cannabinoids

(then wait for room temperature)

$500 \mu \mathrm{L}$ cold acetonitrile

(wait at $60^{\circ} \mathrm{C}$ for 3 hours) 


\section{Table 2. MRM transitions, retention times, and conditions of each molecule}

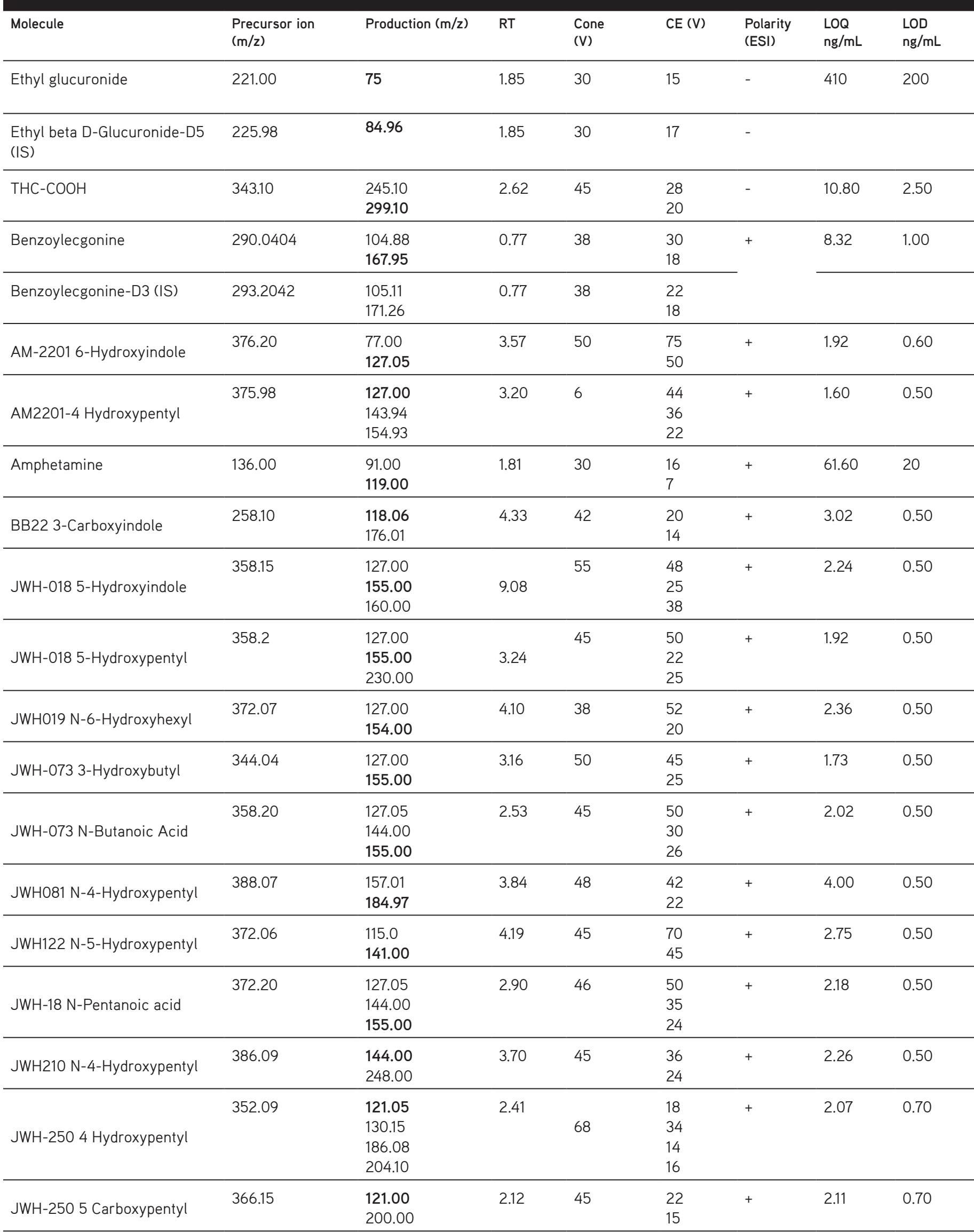


Table 2. Continue

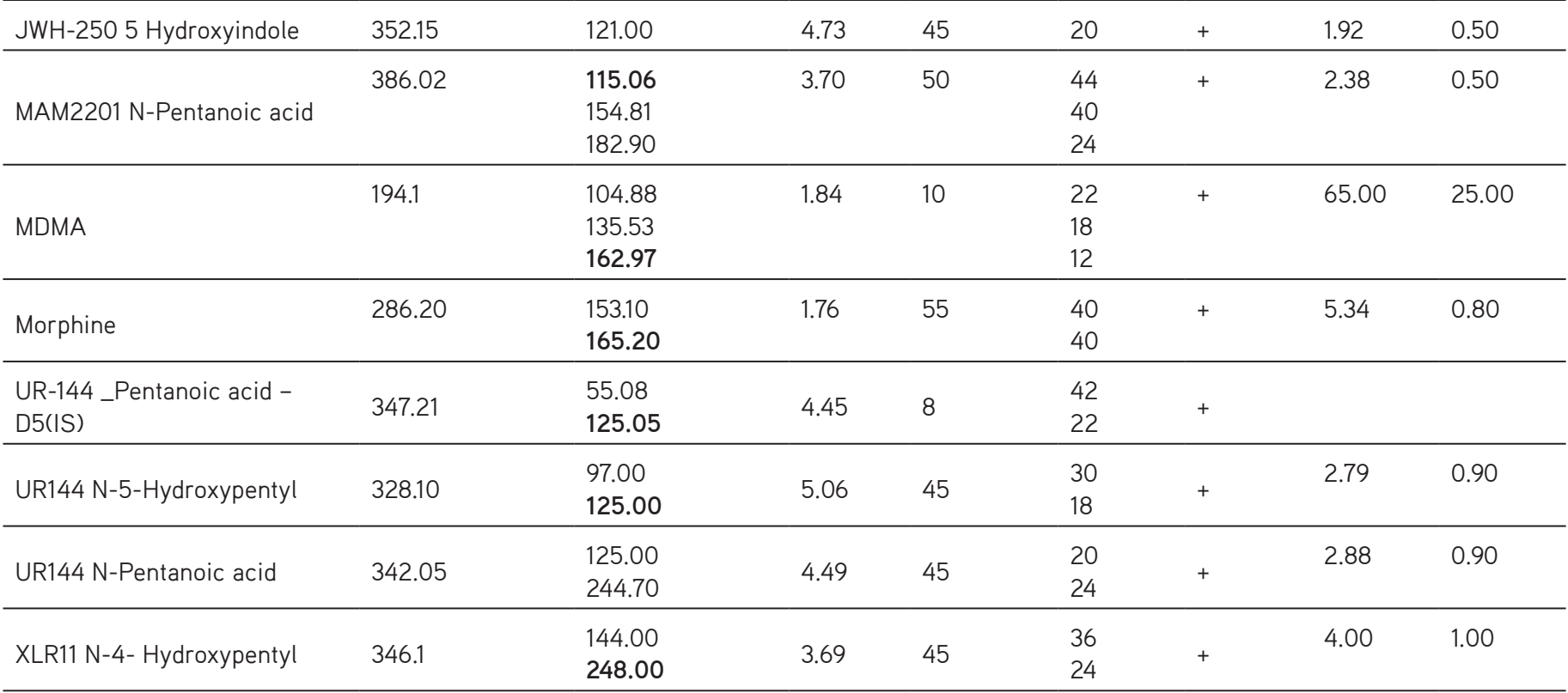

Underlined transitions were used for quantification; RT: retention time; CE: collision energy; ESI: electrospray ionization; IS: internal standard; LOQ: limit of quantitation; LOD: limit of detection

Table 3. Substance abuse profile of 293 patients

\begin{tabular}{|c|c|c|c|c|c|c|c|c|c|c|c|c|c|c|}
\hline \multirow[t]{2}{*}{ Substance } & \multicolumn{2}{|c|}{ Alcohol } & \multicolumn{2}{|c|}{ Cocaine } & \multicolumn{2}{|c|}{ Morphine } & \multicolumn{2}{|c|}{ Amphetamine } & \multicolumn{2}{|c|}{ MDMA } & \multicolumn{2}{|c|}{ Cannabis } & \multicolumn{2}{|c|}{$\begin{array}{l}\text { Synthetic } \\
\text { cannabinoids }\end{array}$} \\
\hline & $n$ & $\%$ & $n$ & $\%$ & $n$ & $\%$ & $n$ & $\%$ & $n$ & $\%$ & $n$ & $\%$ & $n$ & $\%$ \\
\hline Users & 97 & 33.11 & 68 & 23.21 & 72 & 24.57 & 16 & 5.46 & 23 & 7.85 & 101 & 34.47 & 32 & 10.92 \\
\hline
\end{tabular}

$\mathrm{n}$ : analyzed urine sample; \%: percentage of substance abuse

\section{Statistical analysis}

Statistical assessment was performed on the analysis reports to determine the substance use profiles of the patients admitted to the AMATEM unit. The results were statistically evaluated using the chi-square test. The level of significance was $p \leq 0.05$ at a $95 \%$ significance level.

\section{RESULTS}

When the analysis reports of the urine samples obtained during the initial admission periods of 600 patients were observed, 293 of the patients were identified to have used addictive substances. Statistical analysis was conducted by taking the data of the 293 patients with addictive substances into consideration in order to determine their substance abuse profiles.

In Table 3, it can be seen that of the 293 patients, 97 patients (33.1\%) consumed alcohol, 68 (23.2\%) used cocaine, 72 used (24.6\%) morphine, 16 (5.5\%) used amphetamine, 23 (7.8\%) used MDMA, 101 (34.5\%) smoked cannabis, and 32 (10.9\%) used synthetic cannabinoids. In compliance with the data, the top three substances consumed by the 293 patients were cannabis, alcohol, and morphine respectively (Figure 1).

As seen in Figure 2, 260 (88.74\%) of 293 patients were male and 33 (11.26\%) were female. As shown in Table 4, there was no statistical correlation between individual substance consumption and sex at a 95\% significance level ( $p>0.05)$ (Figure 3).

When the age groups of the 293 patients were considered, there were 57 (19.45\%) people in 13-22 years age group, 159 (54.27\%) people in 23-32 years age group, 51 (17.41\%) people in 33-42 age group, 17 (5.80\%) people in $43-52$ years age group, and 9 people aged 53 years and above (3.07\%) (Figure 4).

As shown in Table 5, there were correlations between age and consumption of alcohol, cannabis, and morphine at the $95 \%$ significance level $(p \leq 0.05)$. There was no correlation between age and consumption of cocaine, amphetamine, MDMA, and synthetic cannabinoids at the $95 \%$ significance level $(p>0.05)$ (Figure 5).

Nineteen types of synthetic cannabinoid molecules were analyzed in the urine samples in order to detect the use of 


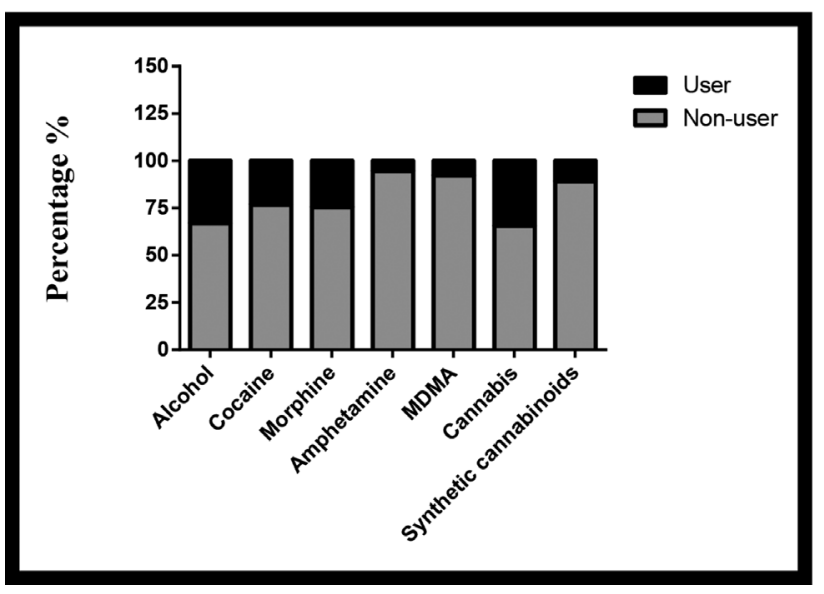

Figure 1. Percentage distribution of substance abuse by 293 patients

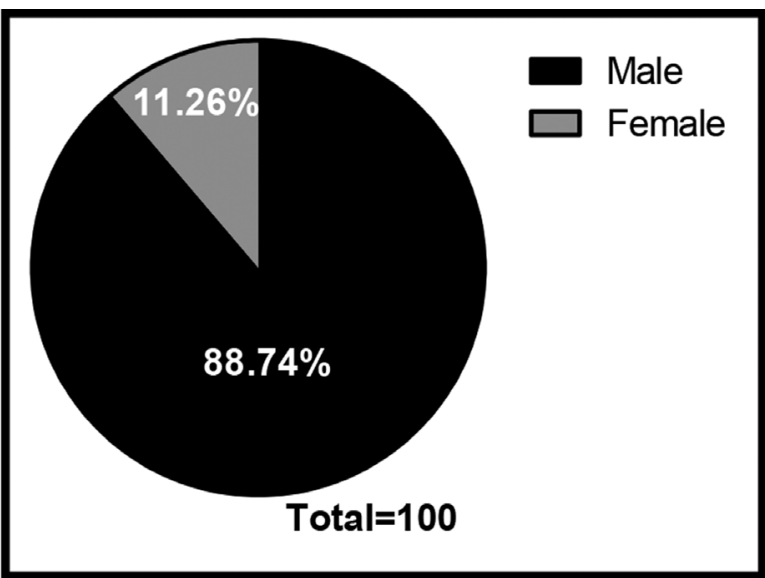

Figure 2. Two hundred nineteen three patients' percentage distribution according to gender

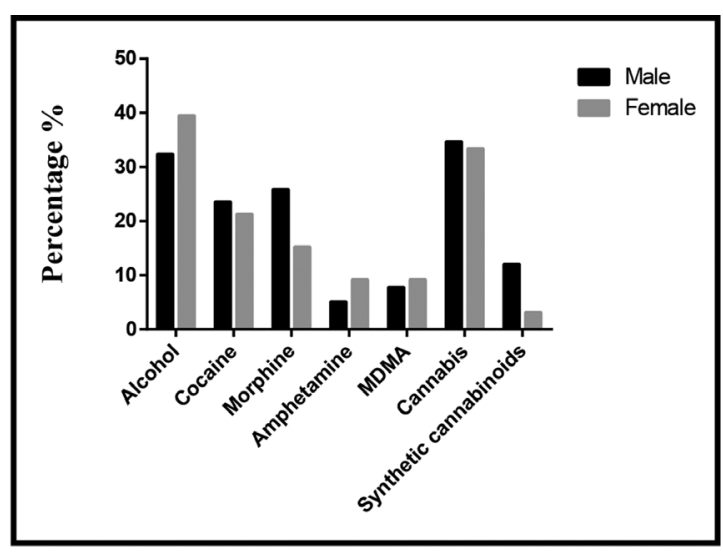

Figure 3. Substance abuse profile of 293 patients according to gender

synthetic cannabinoids. As a result, a total of 59 synthetic cannabinoid molecules were detected to have been used by 32 of 293 patients: $25.42 \%$ UR144 N-pentanoic acid, $20.34 \%$ UR144 N-5-hydroxypentyl, $18.64 \%$ JWH-18 N-pentanoic acid, 8.47\% JWH-018 5-hydroxypentyl, 5.08\% JWH-018

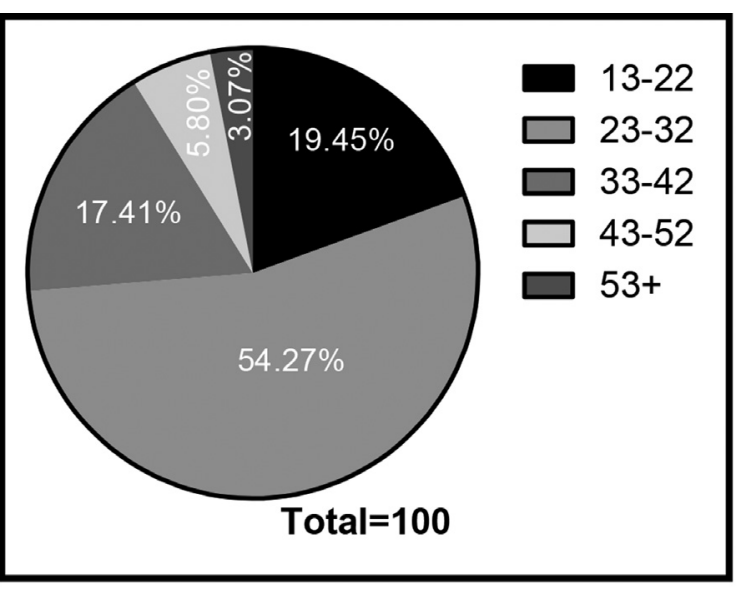

Figure 4. Two hundred nineteen three patients' percentage distribution according to age

Table 4. Substance abuse profile of 293 patients according to sex

\begin{tabular}{|c|c|c|c|c|c|}
\hline Substance & \multicolumn{2}{|c|}{ Male $(n=260)$} & \multicolumn{2}{|c|}{ Female $(n=33)$} & Statistical \\
\hline \multicolumn{6}{|l|}{ Alcohol } \\
\hline Non-users & 176 & $67.69 \%$ & 20 & $60.61 \%$ & \multirow{2}{*}{$\begin{array}{l}\chi^{2}=0.664, \\
p=0.289\end{array}$} \\
\hline Users & 84 & $32.31 \%$ & 13 & $39.39 \%$ & \\
\hline \multicolumn{6}{|l|}{ Cocaine } \\
\hline Non-users & 199 & $76.54 \%$ & 26 & $78.79 \%$ & \multirow{2}{*}{$\begin{array}{l}\chi^{2}=0.773 \\
p=0.773\end{array}$} \\
\hline Users & 61 & $23.46 \%$ & 7 & $21.21 \%$ & \\
\hline \multicolumn{6}{|l|}{ Morphine } \\
\hline Non-users & 193 & $74.23 \%$ & 28 & $84.85 \%$ & \multirow{2}{*}{$\begin{array}{l}\chi^{2}=1.781 \\
p=0.182\end{array}$} \\
\hline Users & 67 & $25.77 \%$ & 5 & $15.15 \%$ & \\
\hline \multicolumn{6}{|c|}{ Amphetamine } \\
\hline Non-users & 247 & $95.00 \%$ & 30 & $90.91 \%$ & \multirow{2}{*}{$\begin{array}{l}\chi^{2}=0.949 \\
p=0.330\end{array}$} \\
\hline Users & 13 & $5.00 \%$ & 3 & $9.09 \%$ & \\
\hline \multicolumn{6}{|l|}{ MDMA } \\
\hline Non-users & 240 & $92.31 \%$ & 30 & $90.91 \%$ & \multirow{2}{*}{$\begin{array}{l}\chi^{2}=0.079 \\
p=0.778\end{array}$} \\
\hline Users & 20 & $7.69 \%$ & 3 & $9.09 \%$ & \\
\hline \multicolumn{6}{|l|}{ Cannabis } \\
\hline Non-users & 170 & $65.38 \%$ & 22 & $66.67 \%$ & \multirow{2}{*}{$\begin{array}{l}\chi^{2}=0.021 \\
p=0.884\end{array}$} \\
\hline Users & 90 & $34.62 \%$ & 11 & $33.33 \%$ & \\
\hline \multicolumn{6}{|c|}{ Synthetic cannabinoids } \\
\hline Non-users & 229 & $88.08 \%$ & 32 & $96.97 \%$ & \multirow{2}{*}{$\begin{array}{l}\chi^{2}=2.38 \\
p=0.123\end{array}$} \\
\hline Users & 31 & $11.92 \%$ & 1 & $3.03 \%$ & \\
\hline
\end{tabular}

5-hydroxyindole, 8.47\% AM-2201 6-hydroxyindole, 5.08\% AM2201 4-hydroxyindole, 3.39\% JWH-250 5-hydroxyindole, 1.69\% JWH-073 N-butanoic acid, 1.69\% JWH-073 3-hydroxybutyl, and $1.69 \%$ BB22 3-carboxyindole existed in the 59 synthetic cannabinoid molecules detected. JWH019 N-6-hydroxyhexyl, 
JWH081 N-4-hydroxypentyl, JWH122 N-5-hydroxypentyl, JWH210 N-4-hydroxypentyl, JWH-250 5-carboxypentyl, JWH250 4-hydroxypentyl, MAM2201 N-pentanoic acid, XLR11 $\mathrm{N}$-4-hydroxypentyl molecules were not identified in the urine samples (Figure 6).

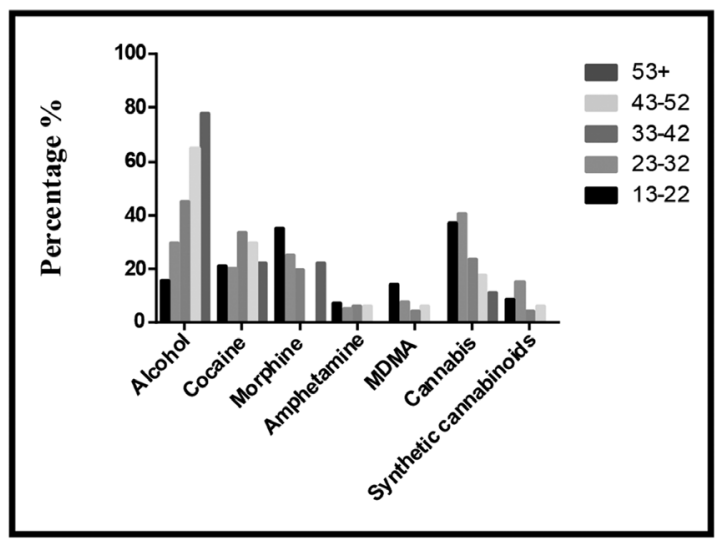

Figure 5. Substance abuse profile of 293 patients according to age groups
When the multiple substance abuse of 293 patients was assessed, abuse of two or more substances was identified in 97 patients. In the 97 patients, use of two substances was identified in $76(78.35 \%)$ patients, use of three in $16(17.53 \%)$, and use of four substances was identified in 4 patients (4.12\%) (Figure 7). The distribution of multiple-substance abuser patients' results is given in Table 6.

\section{DISCUSSION}

Alcohol and substance addiction is amongst the leading factors causing significant problems in Turkey as it does around the world. ${ }^{8}$ According to UNODC data, 1.6 million drug seizure cases took place around the world in 2006. Sixty-five percent of the drugs seizes was cannabis, $14 \%$ was opium and derivatives, $9 \%$ was coca plant and derivatives, $2 \%$ ecstasy, and $5 \%$ amphetamines. ${ }^{5}$ In the UNODC 2015 world drug report, it stated that the most commonly used drugs of patients aged 15-64 years were cannabis, cocaine, and amphetamine derivatives. ${ }^{1,2}$ Turkey is affected by world drug marketing both as a transit and target country. Cannabis, opiates, cocaine, amphetamine

Table 5. Substance abuse profile of 293 patients according to age groups

\begin{tabular}{|c|c|c|c|c|c|c|c|c|c|c|c|}
\hline \multirow{2}{*}{$\begin{array}{l}\text { Substance } \\
\text { Alcohol }\end{array}$} & \multicolumn{11}{|c|}{ Age (among all users) (years) } \\
\hline & \multicolumn{2}{|c|}{$\begin{array}{l}13-22 \\
(n=57)\end{array}$} & \multicolumn{2}{|c|}{$\begin{array}{l}23-32 \\
(n=159)\end{array}$} & \multicolumn{2}{|c|}{$\begin{array}{l}33-42 \\
(n=51)\end{array}$} & \multicolumn{2}{|c|}{$\begin{array}{l}43-52 \\
(n=17)\end{array}$} & \multicolumn{2}{|c|}{$\begin{array}{l}53+ \\
(n=9)\end{array}$} & $\begin{array}{l}\text { Statistical } \\
\text { results }\end{array}$ \\
\hline Non-users & 48 & $84.21 \%$ & 112 & $70.44 \%$ & 28 & $54.90 \%$ & 6 & $35.29 \%$ & 2 & $22.22 \%$ & \multirow{2}{*}{$\begin{array}{l}\chi^{2}=27.708 \\
p<0.001\end{array}$} \\
\hline Users & 9 & $15.79 \%$ & 47 & $29.56 \%$ & 23 & $45.10 \%$ & 11 & $64.71 \%$ & 7 & $77.78 \%$ & \\
\hline \multicolumn{12}{|l|}{ Cocaine } \\
\hline Non-users & 45 & $78.95 \%$ & 127 & $79.87 \%$ & 34 & $66.67 \%$ & 12 & $70.59 \%$ & 7 & $77.78 \%$ & \multirow{2}{*}{$\begin{array}{l}\chi^{2}=4.302 \\
p=0.367\end{array}$} \\
\hline Users & 12 & $21.05 \%$ & 32 & $20.13 \%$ & 17 & $33.33 \%$ & 5 & $29.41 \%$ & 2 & $22.22 \%$ & \\
\hline \multicolumn{12}{|l|}{ Morphine } \\
\hline Non-users & 37 & $64.91 \%$ & 119 & $74.84 \%$ & 41 & $80.39 \%$ & 17 & $100.00 \%$ & 7 & $77.78 \%$ & \multirow{2}{*}{$\begin{array}{l}\chi^{2}=9.673 \\
p=0.046\end{array}$} \\
\hline Users & 20 & $35.09 \%$ & 40 & $25.16 \%$ & 10 & $19.61 \%$ & 0.00 & $0.00 \%$ & 2 & $22.22 \%$ & \\
\hline \multicolumn{12}{|c|}{ Amphetamine } \\
\hline Non-users & 53 & $92.98 \%$ & 151 & $94.97 \%$ & 48 & $94.12 \%$ & 16 & $94.12 \%$ & 9 & $100.00 \%$ & \multirow{2}{*}{$\begin{array}{l}\chi^{2}=0.868 \\
p=0.929\end{array}$} \\
\hline Users & 4 & 7.02 & 8 & $5.03 \%$ & 3 & $5.88 \%$ & 1 & $5.88 \%$ & 0 & $0.00 \%$ & \\
\hline \multicolumn{12}{|l|}{ MDMA } \\
\hline Non-users & 49 & $85.96 \%$ & 147 & $92.45 \%$ & 49 & $96.08 \%$ & 16 & $94.12 \%$ & 9 & $100.00 \%$ & \multirow{2}{*}{$\begin{array}{l}\chi^{2}=4.98 \\
p=0.289\end{array}$} \\
\hline Users & 8 & $14.04 \%$ & 12 & $7.55 \%$ & 2 & $3.92 \%$ & 1 & $5.88 \%$ & 0 & $0.00 \%$ & \\
\hline \multicolumn{12}{|l|}{ Cannabis } \\
\hline Non-users & 36 & $63.16 \%$ & 95 & $59.75 \%$ & 39 & $76.47 \%$ & 14 & $82.35 \%$ & 8 & $88.89 \%$ & \multirow{2}{*}{$\begin{array}{l}\chi^{2}=9.501 \\
p=0.05\end{array}$} \\
\hline Users & 21 & $36.84 \%$ & 64 & $40.25 \%$ & 12 & $23.53 \%$ & 3 & $17.65 \%$ & 1 & $11.11 \%$ & \\
\hline \multicolumn{12}{|c|}{ Synthetic cannabinoids } \\
\hline Non-users & 52 & $91.23 \%$ & 135 & $84.91 \%$ & 49 & $96.08 \%$ & 16 & $94.12 \%$ & 9 & $100.00 \%$ & \multirow{2}{*}{$\begin{array}{l}\chi^{2}=7.23 \\
p=0.124\end{array}$} \\
\hline Users & 5 & $8.77 \%$ & 24 & $15.09 \%$ & 2 & $3.92 \%$ & 1 & $5.88 \%$ & 0 & $0.00 \%$ & \\
\hline
\end{tabular}

$\mathrm{n}$ : analyzed urine sample; \%: percentage of substance abuse; $\alpha$ : 0.05 


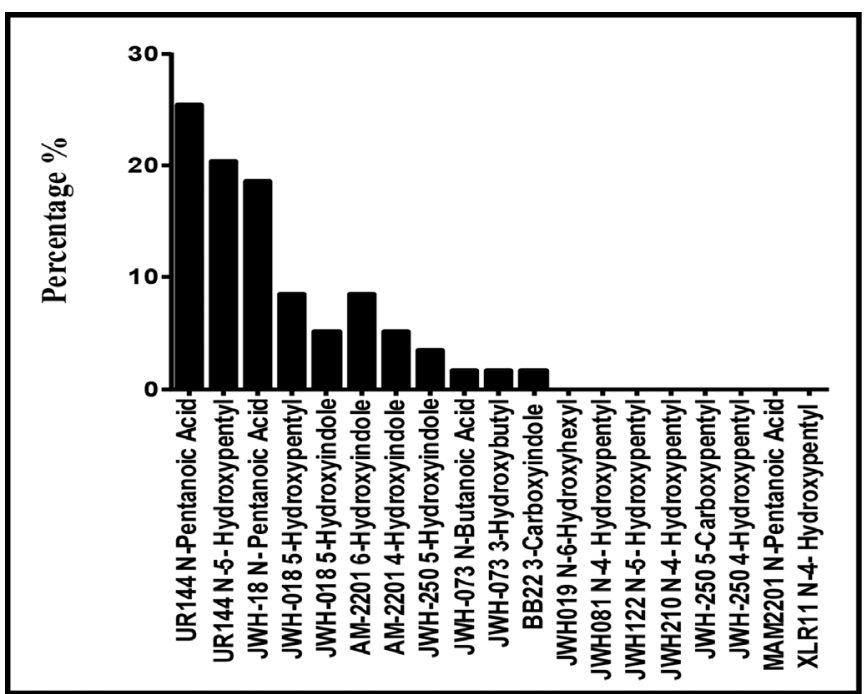

Figure 6. Percentage distribution of 19 types of Synthetic cannabinoids The percentage distribution of $25.42 \%$ UR144 N-Pentanoic acid, $20.34 \%$ UR144 N-5-Hydroxypentyl, 18.64\% JWH-18 N-Pentanoic acid, $8.47 \%$ JWH-018 5-Hydroxypentyl, 5.08\% JWH-018 5-Hydroxyindole, 8.47\% AM2201 6-Hydroxyindole, 5.08\% AM-2201 4-Hydroxyindole, 3.39\% JWH250 5-Hydroxyindole, 1.69\% JWH-073 N-Butanoic acid, 1.69\% JWH-073 3-Hydroxybutyl, 1.69\% BB22 3-Carboxyindole, 0.00\% JWH019 N-6Hydroxyhexyl, 0.00\% JWH081 N-4-Hydroxypentyl, 0.00\% JWH122 N-5Hydroxypentyl, $0.00 \% \quad J W H 210 \quad \mathrm{~N}-4$-Hydroxypentyl, $0.00 \% \quad J W H-250$ 5-Carboxypentyl, 0.00\% JWH-250 4-Hydroxypentyl, 0.00\% MAM2201NPentanoic acid, $0.00 \%$ XLR11 N-4-Hydroxypentyl molecules in the patients diagnosed with Synthetic cannabinoids in their urine samples

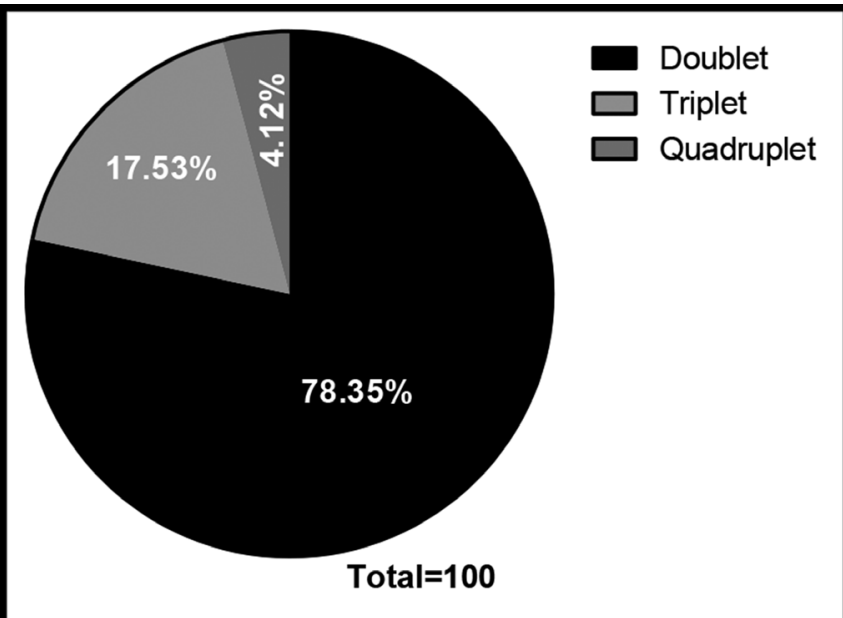

Figure 7. Percentage distribution of the multiple substances identified in the urine of the patients

The percentage distribution of the double, triple, and quadruple substance use of 97 patients who were identified to have used more than one substance with the analysis of their urine samples

derivatives, and synthetic cannabinoids are present amongst the drugs mainly seized in Turkey. ${ }^{8}$

Alcohol consumption is on the rise all around the world, most particularly in developing countries and countries in transition. To illustrate, alcohol consumption increase is faster in Eastern Europe, Russia, and the West Pacific Region. ${ }^{9}$ Erhan Deveci et
Table 6. Percentage distribution of the substance abuse of patients who were identified to have used multiple substances

\begin{tabular}{|c|c|c|}
\hline Substance & $\mathrm{n}$ & $\%$ \\
\hline \multicolumn{3}{|l|}{ Alcohol $(n=35)$} \\
\hline Alcohol + Cannabis & 22 & 62.86 \\
\hline Alcohol + Cocaine & 13 & 37.14 \\
\hline Alcohol + Morphine & 9 & 25.71 \\
\hline Alcohol + MDMA & 3 & 8.57 \\
\hline Alcohol + Synthetic cannabinoids & 1 & 2.86 \\
\hline \multicolumn{3}{|l|}{ Cocaine $(n=45)$} \\
\hline Cocaine + Alcohol & 13 & 28.89 \\
\hline Cocaine + Morphine & 16 & 35.56 \\
\hline Cocaine + Amphetamine & 3 & 2.86 \\
\hline Cocaine + MDMA & 5 & 11.11 \\
\hline Cocaine + Cannabis & 25 & 55.56 \\
\hline Cocaine + Synthetic cannabinoids & 1 & 2.22 \\
\hline \multicolumn{3}{|l|}{ Cannabis $(n=70)$} \\
\hline Cannabis + Alcohol & 22 & 31.43 \\
\hline Cannabis + Cocaine & 25 & 37.71 \\
\hline Cannabis + Morphine & 16 & 22.86 \\
\hline Cannabis + Amphetamine & 2 & 2.76 \\
\hline Cannabis + MDMA & 16 & 22.86 \\
\hline Cannabis + Synthetic cannabinoid & 11 & 15.71 \\
\hline \multicolumn{3}{|l|}{ Morphine $(n=31)$} \\
\hline Morphine + Alcohol & 9 & 29.03 \\
\hline Morphine + Cocaine & 16 & 51.61 \\
\hline Morphine + MDMA & 2 & 6.45 \\
\hline Morphine + Cannabis & 16 & 51.61 \\
\hline Morphine + Synthetic cannabinoids & 1 & 3.23 \\
\hline \multicolumn{3}{|l|}{ Amphetamine $(n=6)$} \\
\hline Amphetamine + Cocaine & 3 & 50.00 \\
\hline Amphetamine + MDMA & 2 & 33.33 \\
\hline Amphetamine + Cannabis & 2 & 33.33 \\
\hline \multicolumn{3}{|l|}{ MDMA $(n=19)$} \\
\hline MDMA + Alcohol & 3 & 15.79 \\
\hline MDMA + Cocaine & 5 & 26.33 \\
\hline MDMA + Morphine & 2 & 10.53 \\
\hline MDMA + Amphetamine & 2 & 10.53 \\
\hline MDMA + Cannabis & 16 & 84.21 \\
\hline MDMA + Synthetic cannabinoids & 2 & 10.53 \\
\hline \multicolumn{3}{|l|}{ Synthetic Cannabinoids $(n=12)$} \\
\hline Synthetic cannabinoids + Alcohol & 1 & 8.33 \\
\hline Synthetic cannabinoids + Cocaine & 1 & 8.33 \\
\hline Synthetic cannabinoids + Morphine & 1 & 8.33 \\
\hline Synthetic cannabinoids + MDMA & 2 & 16.67 \\
\hline Synthetic cannabinoids + Cannabis & 11 & 91.67 \\
\hline
\end{tabular}

$\mathrm{n}$ : analyzed urine sample; \%: percentage of substance abuse 
al. ${ }^{10}$ conducted a study with 2258 Turkish university students, of which $70.3 \%$ were males and $29.7 \%$ were females. They reported that $30.25 \%$ of the males and $19.1 \%$ of the females used alcohol. ${ }^{10}$ In another study conducted with 396 Turkish university students, $56.6 \%$ were reported to have used alcohol at least once throughout their lives."

In our study, the determination of alcohol and drug use was performed through the assessment of the report models obtained by analyzing urine samples, rather than by a survey or an oral interview.

The determination of ethyl glucuronide, which is a metabolite of alcohol, facilitated this aspect of the research. ${ }^{12}$ Ninetyseven $(33.11 \%)$ of 293 patients used alcohol; $32.31 \%$ of males and $39.39 \%$ of females (Table 3 ). We concluded that sex has no significance with regard to alcohol consumption because no significant difference was identified between the sexes with regards alcohol consumption (Table 4). Although men were stated to use more alcohol in the Erhan Deveci et al. ${ }^{10}$ interviews, in our study, we determined no significant correlation between sex and alcohol use. The difference between the two studies could be a result of the use of two different research methods.

In a study Asan et al..$^{13}$ on the sociodemographic attributes of patients treated at an AMATEM unit, the age average of the patients treated for alcohol addiction was determined as higher than the age average of the those treated for substance abuse. In our study, a difference between age and alcohol consumption was identified to exist when the patients who were detected to have used substances were divided into age groups. Alcohol consumption was observed to increase in percentage as age increased (Table 5). The findings in our study show a resemblance to those in the literature.

In 2003, a French study by Mura et al. ${ }^{14}$ aimed to determine the prevalence of alcohol, cannabinoids, opiates, cocaine metabolites, amphetamines, and therapeutic psychoactive drugs in blood samples from drivers injured in road accidents; the substances they determined most frequently were, in order, alcohol, cannabinoids, benzodiazepines, and opiates. Similarly, in our study, we saw alcohol, cannabis, and morphine most commonly, and this shows similarity with the literature.

Benzoylecgonine, which can be detected for 2-3 days in the urine as a metabolite of cocaine, was tested for in the present study. 7,15 Sixty-eight of the 293 patients (23.21\%) used cocaine (Table 3). There was no statistical correlation between cocaine consumption and sex (Table 4). No correlation between age and cocaine could be found (Table 5). In a study on the substance use profile of the public of Iran, cocaine and the other stimulants were reported as negligible. ${ }^{16}$ In our study, we determined cocaine in $23.21 \%$ of our patients' urine samples. The fact that this average is higher in our country could be the result of our country's location as a transition point in world drug market. ${ }^{8}$

The use of opiates was determined in line with resulting free morphine levels. By converting into free morphine, morphine glucuronide, which can be detected for up to 48 hours in the urine as a metabolite of heroine, codeine, and morphine, was considered in the analysis in our study to determine opiate- based substances. ${ }^{17}$ When the results of the analysis were taken into consideration, free morphine was detected in the urine samples of 72 of 293 patients (24.57\%), who were thereby determined to have used opiates (Table 3 ). In a study on the substance use profile of Iranian public, morphine was in first place. ${ }^{16}$ Likewise, in our study, we determined a high incidence of morphine use in the urine samples. However, no correlation between sex and morphine could be found (Table 4). When the age groups were assessed, a significant difference between age and morphine use was observed. Morphine was determined to be mostly used in the age groups of 13-22 years and 23-32 years (Table 5).

Amphetamine can be detected for 1-3 days in the urine. ${ }^{7}$ In our study, amphetamine was detected in the urine samples of 16 of $293(5.46 \%)$ patients (Table 3 ). No difference was observed when the use of amphetamine was evaluated with regard to sex and age groups (Table 4, 5). However, surprisingly, use of amphetamine was not be detected in patients aged 53 and above. MDMA can be detected for 1-3 days in the urine. ${ }^{7}$ In our study, MDMA was detected in the urine samples of 23 of 293 (7.85\%) patients (Table 3 ). No difference was observed when the use of MDMA was evaluated with regard to sex and age groups (Table 4,5). Similarly, use of MDMA was not detected in patients aged 53 and above.

Cannabis is amongst the most frequently used drugs in many countries such as the United Kingdom and the United States of America. It has been reported that the $20 \%$ of the youth living in these countries use cannabis at least once a week. ${ }^{8}$ Cannabis is used widely by young people throughout the world. ${ }^{18,19}$

In a study, it was concluded that young people aged between 1217 years purchased cannabis more than those aged between 50 and 64 years, and the use of cannabis was greater in amongst the young. In the same study, the use of cannabis was reported stated to be higher amongst males compared with females. ${ }^{20} \mathrm{~A}$ metabolite of cannabis, 11-nor-THC-9-carboxylic acid, can be detected for long periods in the urine. ${ }^{21}$ In our study, cannabis was detected in the urine samples of 101 of 293 (34.47\%) patients (Table 3). Although no difference between sex and use of cannabis was observed in our study (Table 4), a difference was determined to exist between the age groups and use of cannabis. The use of cannabis in the age groups of 13-22 years and 23-32 years, which are regarded as the young population, was determined to be higher than that of the other age groups (Table 5). The findings in our study resemble rates of cannabis use by young people throughout the world.

Drugs that containing synthetic cannabinoids in Turkey are known as Bonsai, and K2, spice, aroma, and dream in the global market have been widely used since $2006 .{ }^{4}$ In July 2012, the United States Drug Enforcement Agency classified JWH-018, JWH-019, JWH-073, JWH-081, JWH-122, JWH-200, JWH-203, JWH-250, JWH-398, AM694, AM2201, RCS-4, RCS-8, HU-210, CP 47, 497-C7, CP 47, 497-C8 and their analogs as Schedule I controlled substances. Recently, UR-144, XLR11, and AKB48 were added to the Schedule I controlled substance list. Many countries use the same list. ${ }^{22}$ In a study, synthetic cannabinoids 
were detected in the blood samples of 29 patients aged 14 to 30 years who were admitted to the emergency service between 2008 and 2011, 25 of whom were males and 4 were females. During 2008-2009, JWH-018 was popular, in 2010, it was JWH122 , and in 2011, JWH-210 was widely detected. ${ }^{23}$ In our study, synthetic cannabinoids were detected in the urine samples of 32 patients out of 293 (10.92\%) (Table 3). No difference was observed when the use of synthetic cannabinoids was evaluated with regard to sex and age groups (Table 4, 5). However, similar to MDMA and amphetamines, use of synthetic cannabinoids was not detected in patients aged 53 years and above.

In our study, 19 types of synthetic cannabinoid molecules were analyzed in urine samples in order to detect the use of synthetic cannabinoids. As a result of the analysis, a total of 59 synthetic cannabinoid molecules were detected to be used by 32 of 293 patients (Figure 6). The top ranking metabolites of the 19 different synthetic cannabinoid molecules were respectively: UR144 N-pentanoic acid, UR144 N-5-hydroxypentyl, JWH18 N-pentanoic acid, JWH-018 5-hydroxypentyl, AM-2201 6-hydroxyindole, JWH-018 5-hydroxyindole, AM-2201 4-hydroxyindole, JWH-250 5-hydroxyindole, JWH-073 N-butanoic acid, JWH-073 3-hydroxybutyl, and BB22 3-carboxyindole.

UR144 N-pentanoic acid, UR144 N-5-hydroxypentyl, and JWH$18 \mathrm{~N}$-pentanoic acid were most frequently detected in the urine samples. The findings in our study and literature show differences in consumption of synthetic cannabinoids because the variety of synthetic cannabinoids changes rapidly around the world each year.

When the percentage distribution of the double, triple, and quadruple substance use of 97 patients who were identified to have used more than one substance was taken into consideration (Figure 7), it was determined that the use of cannabis $(62.86 \%)$ was most common with alcohol, the use of cannabis (55.56\%) was the most common with cocaine, the use of cannabis $(51.61 \%)$ and cocaine $(51.61 \%)$ were most common with morphine, the use of cocaine $(50.00 \%)$ was the most common with amphetamines, the use of cannabis $(84.21 \%$ ) was the most common with MDMA, the use of cocaine (37.71\%) was the most common with cannabis, and the use of cannabis (91.67\%) was most common with synthetic cannabinoids (Table 6 ).When the results of the study are taken into consideration, the use of cannabis was widely observed in patients who used more than one drug.

To summarize our study, the drugs mostly detected in the urine samples of 293 patients were cannabis, alcohol, morphine, cocaine, synthetic cannabinoids, MDMA, and amphetamine, respectively. Cannabis took first place, and amphetamine was the least popular. Sex appeared to play no significant role in the preference of substance use. The rate of substance abuse according to age groups showed variations for alcohol, morphine, and cannabis. The use of alcohol increased in percentage as age increased. Use of morphine and cannabis was common amongst the young population. The most commonly detected molecules of the 19 synthetic cannabinoids that were subjected to analysis were: UR144 N-pentanoic acid, UR144 N-5-hydroxypentyl, JWH-18 N-pentanoic acid, JWH018 5-hydroxypentyl, JWH-018 5-hydroxyindole, AM-2201 6-hydroxyindole, and AM-22014-hydroxyindole. The use of cannabis was widely observed in patients who used more than one drug.

\section{CONCLUSION}

The prevalence of alcohol and drug use in Turkey is considered to be at substantial levels and does not qualify as negligible. The data reflecting the dimensions of substance dependence in Turkey is known to heavily rely on arrests by Narcotics Police and some survey data, and statistical assessments of data obtained through analysis of biologic materials are limited. More reliable assessments are considered to be achieved by integrating analytically obtained data such as those in our study, together with data of surveys used in the determination of substance abuse profiles around Turkey and the world, or information received from national departments that investigate smuggling.

Conflict of Interest: No conflict of interest was declared by the authors.

\section{REFERENCES}

1. Smart RG, Ogborne AC. Drug use and drinking among students in 36 countries. Addict Behav. 2000;25:455-460.

2. UNODC. World Drug Report 2015, 2015.

3. UNODC. World Drug Report 2011, 2011.

4. Every-Palmer $\mathrm{S}$. Warning: legal synthetic cannabinoid-receptor agonists such as JWH-018 may precipitate psychosis in vulnerable individuals. Addiction. 2010;105:1859-1860.

5. The Grand National Assembly of Turkey The Parliamentary Inquiry Commission Established to Search for Problems Regarding Substances SD, Dependence, Drug Trafficking and to Discern the Necessary Precautions. The problems determined in the area of substance use and dependence, in the prevention of drug trafficking and recommendations offered, 2009.

6. TUBIM. Turkish drug report 2012, 2012.

7. Verstraete AG. Detection times of drugs of abuse in blood, urine, and oral fluid. Ther Drug Monit. 2004;26:200-205.

8. TUBIM. Turkish drug report 2014, 2014.

9. Monteiro MG. A World Health Organization perspective on alcohol and illicit drug use and health. Eur Addict Res. 2001;7:98-103.

10. Erhan Deveci S, Açik Y, Ferdane Oguzöncül A, Deveci F. Prevalence and factors affecting the use of tobacco, alcohol and addictive substance among university students in eastern Turkey. Southeast Asian J Trop Med Public Health. 2010;41:996-1007.

11. Turhan E, İandia T, Özer C, Akoğlu S. Substance use, violence among university students and their some psychological characteristics. Turkish Journal of Public Health. 2011;9:33-44.

12. Keten A, Zeren C, Arslan MM, Daglıoglu N, Karanfil R, Şen BB. Determination of ethyl glucuronide in fingernails by LC/MS-MS. Rom $J$ Leg Med. 2013;21:67-72. 
13. Asan Ö, Tıkır B, Okay IH, Göka E. Sociodemographic and Clinical Features of Patients with Alcohol and Substance Use Disorders in a Specialized Unit. Journal of Dependence. 2005;16:1-8.

14. Mura $P$, Kintz $P$, Ludes $B$, Gaulier JM, Marquet $P$, Martin-Dupont $S$, Vincent F, Kaddour A, Goullé JP, Nouveau J, Moulsma M, Tilhet-Coartet $\mathrm{S}$, Pourrat $\mathrm{O}$. Comparison of the prevalence of alcohol, cannabis and other drugs between 900 injured drivers and 900 control subjects: results of a French collaborative study. Forensic Sci Int. 2003;133:79-85.

15. Cengiz G, Cecen SS, Soylemezoglu T. Determination of cocaine in urine by GC/MS method. Journal of Faculty of Pharmacy of Ankara University. 2004;33:125-149.

16. Mokri A. Brief overview of the status of drug abuse in Iran. Arch Iranian Med. 2002;5:184-190.

17. Duydu Y. Simultaneous determination of morphine, codeine and 6-monoacetyl morphine in urine by GC/MS method. Journal of Faculty of Pharmacy of Ankara University. 1998;27:101-113.

18. Moore TH, Zammit S, Lingford-Hughes A, Barnes TR, Jones PB, Burke $M$, Lewis $G$. Cannabis use and risk of psychotic or affective mental health outcomes: a systematic review. Lancet. 2007;370:319-328.
19. Silins E, Fergusson DM, Patton GC, Horwood LJ, Olsson CA, Hutchinson DM, Degenhardt L, Tait RJ, Borschmann R, Coffey C, Toumbourou JW, Najman JM, Mattick RP; Cannabis Cohorts Research Consortium. Adolescent substance use and educational attainment: An integrative data analysis comparing cannabis and alcohol from three Australasian cohorts. Drug Alcohol Depend. 2015;156:90-96.

20. Burns RM, Caulkins JP, Everingham SS, Kilmer B. Statistics on cannabis users skew perceptions of cannabis use. Front Psychiatry. 2013;4:138.

21. Grauwiler SB, Scholer A, Drewe J. Development of a LC/MS/MS method for the analysis of cannabinoids in human EDTA-plasma and urine after small doses of Cannabis sativa extracts. J Chromatogr B Analyt Technol Biomed Life Sci. 2007;850:515-522.

22. Scheidweiler KB, Huestis MA. Simultaneous quantification of 20 synthetic cannabinoids and 21 metabolites, and semi-quantification of 12 alkyl hydroxy metabolites in human urine by liquid chromatographytandem mass spectrometry. J Chromatogr A. 2014;1327:105-117.

23. Hermanns-Clausen M, Kneisel S, Szabo B, Auwärter V. Acute toxicity due to the confirmed consumption of synthetic cannabinoids: clinical and laboratory findings. Addiction. 2013;108:534-544. 